\title{
PHYSIOLOGICAL RESPONSES OF MAIZE AND COWPEA TO INTERCROPPING ${ }^{1}$
}

\author{
JOSÉMOACIRPINHEIRO LIMAFILHO²
}

\begin{abstract}
The effect of intercropping on plant water status, gas exchange and productivity of maize (Zea mays L.) cv. Centralmex, and cowpea (Vigna unguiculata L. (Walp)) cv. Pitiuba were evaluated under semi-arid conditions at the Embrapa-Centro de Pesquisa Agropecuária do Trópico Semi-Árido (CPATSA) at Petrolina, PE, Brazil. The treatments were: maize and cowpea as sole crops, at a population of 40,000 plants ha-1, and intercropped at a population of 20,000 plants $\mathrm{ha}^{-1}$. The results obtained in this paper appear to be related to the degree of competition experienced by the components, mainly for water and light. Maize intercropped had higher values of leaf water potential, stomatal conductance, transpiration and photosynthesis than as sole crop. Intercropped cowpea had higher values of leaf water potential but lower stomatal conductance, transpiration and photosynthesis than sole cowpea. Maize productivity increased $18 \%$ in relation to sole crop whereas a $5 \%$ decrease was observed with cowpea. Despite these facts the Land Equivalent Ratio obtained was 1.13 indicating intercropping advantage over the sole system. The higher partial Land Equivalent Ratio observed for maize suggests that this specie was the main component influencing the final productivity of the intercropping system studied.
\end{abstract}

Index terms: plant soil relations, plant water relations, gas exchange, cropping systems.

\section{RESPOSTAS FISIOLÓGICAS DO MILHO E CAUPI À CONSORCIAÇÃO}

RESUMO - Estudou-se, na Embrapa-Centro de Pesquisa Agropecuária do Trópico Semi-Árido (CPATSA) em Petrolina, PE, o efeito do plantio consorciado sobre o comportamento hídrico, trocas gasosas e produtividade do milho (Zea mays L.) cv. Centralmex, e do caupi (Vigna unguiculata L. (Walp)) cv. Pitiuba, em condições semi-áridas. Os tratamentos foram: milho e caupi em cultivos isolados na população de 40.000 plantas ha $^{-1}$, e consorciados na população de 20.000 plantas ha-1 $^{-1}$. No sistema de consórcio, o milho obteve valores mais altos de potencial hídrico, condutância estomática, transpiração e fotossíntese, em relação ao cultivo isolado. Com o caupi, observaram-se valores mais altos de potencial hídrico, porém menor condutância, transpiração e fotossíntese em relação ao cultivo isolado. Observou-se incremento de $18 \%$ na produtividade do milho, enquanto a do caupi foi reduzida em 5\%, em relação aos respectivos sistemas de monocultivo. Entretanto, o índice de equivalência da terra obtido foi de 1,13, o que indica vantagens do consórcio sobre os sistemas isolados. O maior índice parcial de equivalência de terra foi obtido com o milho, sugerindo que esta espécie foi o principal componente a influenciar a produtividade final do sistema estudado.

Termos para indexação: relação planta-solo, relação planta-água, troca gasosa, sistemas de cultivo.

\section{INTRODUCTION}

Intercropping is the growing of two or more species simultaneously in the same field during a growing season (Ofori \& Stern, 1987) being a traditional

\footnotetext{
1 Accepted for publication on July 12, 1999.

2 Agronomist, M.Sc., Embrapa-Centro de Pesquisa Agropecuária do Trópico Semi-Árido (CPATSA), Caixa Postal 23, CEP 56000-300 Petrolina, PE, Brazil. E-mail: moacir@cpatsa.embrapa.br
}

practice through the tropics. Okigho \& Greenland (1976) described intercropping as the most widespread cropping system in Africa. Also, they estimated that $99 \%$ of cowpea, $95 \%$ of groundnut, $89 \%$ of millet and $75 \%$ of maize grown in Nigeria are intercropped. In North America, interest in this system is growing because its potential for increasing whole field productivity (Fortin \& Pierce, 1996). Francis et al. (1976) estimated that $60 \%$ of maize production and most of bean grown in Latin America come from intercropping. Intercropping is the main cropping sys- 
tem in Northeast Brazil. Among the various combinations adopted by small farmers, maize and cowpea is one of the most used (Morgado \& Rao, 1985).

Intercrops are said to be better than monocrop cultures because they yield more, protect against risks of drought and pests, even out the distribution of labor requirements, and provide a more balanced human diet (Vandermeer, 1990). Moreover, crops differ in the way they use environmental resources. Thus, they can complement each other, when grown together, making better use of resources than as monocrops (Willey, 1979). This complementarity can be regarded as temporal, when the crops make their major demand on resources at different times, or spatial, due to differences in canopy and root dispersion (Willey, 1990).

In recent years there has been an interest on intercropping not only due to reported advantages of this system over monocropping (Allen \& Obura, 1983; Chang \& Shibles, 1985; Olasantan, 1988), but also in searching for detailed knowledge of how different species are able to coexist productively (Vandermeer, 1984). The idea is based on a few wellknown concepts from theoretical ecology whose goal is to find out how the species interact. For example, the competitive production principle will be operative when one species has an effect on the environment that causes a negative response in the other species, yet both can utilize necessary resources more efficiently when living together (Vandermeer, 1981). However, when the environment of one species is modified in a positive way by a second species such that the first is facilitated by the second, the facilitative production principle will come into play (Vandermeer, 1984). Competition for resource develops due to varying time of planting, root growth patterns, and/or different resource demands (Ghaffarzadeh et al., 1997).

Despite the importance of intercropping, very few reports are found in the literature concerning the influences of this system on the environment and physiology of the component species. The available data refer mainly to plant water status (Wahua \& Miller, 1978; Shackel \& Hall, 1984; Távora \& Lopes, 1990).

The objective of this paper was to study the effects of intercropping on the physiological behavior of maize and cowpea based on soil-plant water status and gas exchange measurements and their impact on the productivity of the system. Information on these subjects is essential for a better understanding of the system that will help management decisions.

\section{MATERIAL AND METHODS}

This study was carried out at the Embrapa-Centro de Pesquisa Agropecuária do Trópico Semi-Árido (CPATSA), at Petrolina, PE, Brazil, during the dry season of 1990. Maize (Zea mays L.), cv. Centralmex, and cowpea (Vigna unguiculata L. (Walp)) cv. Pitiuba were sown as sole crops and intercropped on a soil classified as Oxisol. Soil physical characteristics of the experimental area were determined by Choudhury \& Millar (1981). The experimental design was a completely randomized block with three treatments and four replications. The treatments were maize and cowpea as sole crops at a population of 40,000 plants/ha and intercropped at a population of 20,000 plants/ha, under a 1:1 North-South row arrangement. This combination was chosen because these crops have presented yield advantages under intercropping situation (Rao \& Morgado, 1984). Plant spacing was $0.50 \mathrm{~m} \times 0.50 \mathrm{~m}$ for both monocropping and intercropping treatments. Irrigation of the entire experiment was done with an overhead sprinkler system on a weekly basis until soil had reached field capacity. A total of $300 \mathrm{~mm}$ water was applied during the growing period. Soil water status was monitored with a neutron probe (model 3300 , Troxler, USA), at $0.30 \mathrm{~m}$ depth. Two access tubes/species were placed within the rows of the sole and in the intercropping treatments. Data were plotted against a soil moisture release curve previously obtained (Távora \& Lopes, 1990) for determination of soil matric potential $(\psi \mathrm{m})$.

Leaf transpiration $(\mathrm{E})$, stomatal conductance $\left(\mathrm{g}_{\mathrm{s}}\right)$, and photosynthesis (A) were measured with a portable photosynthesis system (LI-6000, LICOR, USA). Measurements were made on the flag leaf for maize, and on the central mature leaflet for cowpea. Leaf water potential $(\psi \mathrm{w})$ was determined with a pressure chamber (PMS Instruments, USA), on the same leaves used in the previous measurements. Maize and cowpea leaf water potential were taken according to Roo (1969) and Turner (1981), respectively.

The photosynthetic active radiation (PAR) distribution profiles were obtained with line quantum sensors and a datalogger (LI-195 S and LI-1000, LICOR, USA) set up above maize and intercropped cowpea canopies. Air temperature $(\mathrm{T})$ and relative humidity $(\mathrm{RH})$ were measured 
using sensors connected to the datalogger at the same height of PAR measurements. The data obtained were used to calculate the Vapor Pressure Deficit (VPD).

Both physiological and environmental factors were monitored in two occasions, between the $40^{\text {th }}$ and the $55^{\text {th }}$ day after sowing, from $6 \mathrm{~h}$ to $18 \mathrm{~h}$, one day before irrigation.

In order to obtain information about the growing stage of the plants at the time of measurements, two plants of each species/plot were randomly harvested at the $50^{\text {th }}$ day after sowing for leaf area determination. Measurements were made with a leaf area meter (LI-3100, LICOR, USA). The data were used to calculate the leaf area index (LAI) for each component.

Harvest was carried out at the $85^{\text {th }}$ and $95^{\text {th }}$ day after sowing for cowpea and at the $135^{\text {th }}$ day for maize. Grain productivity was used to calculate the land equivalent ratio (LER), which expresses yield advantages of intercropping systems over monocrops. The LER was obtained according to Mead \& Willey (1980).

Data were analyzed for statistical significance using the SAS Software (SAS Institute Inc., Cary, NC) through the Student's t test at 5\% probability.

\section{RESULTS AND DISCUSSION}

Lower values of PAR (Fig. 1) were observed above intercropped cowpea indicating significant $(\mathrm{P}<0.05)$ interception by maize leaves mainly during the morning because of row orientation. The greatest variation between systems occurred at $10 \mathrm{~h}$ and $16 \mathrm{~h}$ when about $950 \mu \mathrm{mol} \mathrm{m}^{-2} \mathrm{~s}^{-1}$ and $600 \mu \mathrm{mol} \mathrm{m}^{-2} \mathrm{~s}^{-1}$ were intercepted. The highest values were recorded at noon reaching nearly $1,950 \mu \mathrm{mol} \mathrm{m}^{-2} \mathrm{~s}^{-1}$ above maize and $1,600 \mu \mathrm{mol} \mathrm{m}^{-2} \mathrm{~s}^{-1}$ above intercropped cowpea. Despite the high radiation input and the great variation in the radiation pattern between systems, no significant differences in T and VPD were detected (Fig. 1). However, $1^{\circ} \mathrm{C}$ decrease in $\mathrm{T}$ above the cowpea canopy between $8 \mathrm{~h}$ and $10 \mathrm{~h}$ was observed. The highest $\mathrm{T}$ and VPD were recorded above maize in the afternoon, reaching respectively $37^{\circ} \mathrm{C}$ and $38.75 \mathrm{mbar}$, showing high evapotranspiration conditions during data collection.

Soil $\psi \mathrm{m}$ observed for maize were - $0.07 \mathrm{MPa}$ and $-0.04 \mathrm{MPa}$, respectively, under the sole and intercropped systems (Fig. 2). Because intercropping population was $50 \%$ for either maize and cowpea, and water consumption is higher for maize (Morgado
\& Rao, 1985), it is possible that soil water content just before irrigation was less for sole than for intercropped maize, because of intraspecific competition. Moreover, the radiation intercepted by the intercrop canopy would result in less energy at the soil surface, for water evaporation.

The greater water availability observed under intercropped maize improved plant water status. The data obtained suggest that leaf $\psi w$ was positively
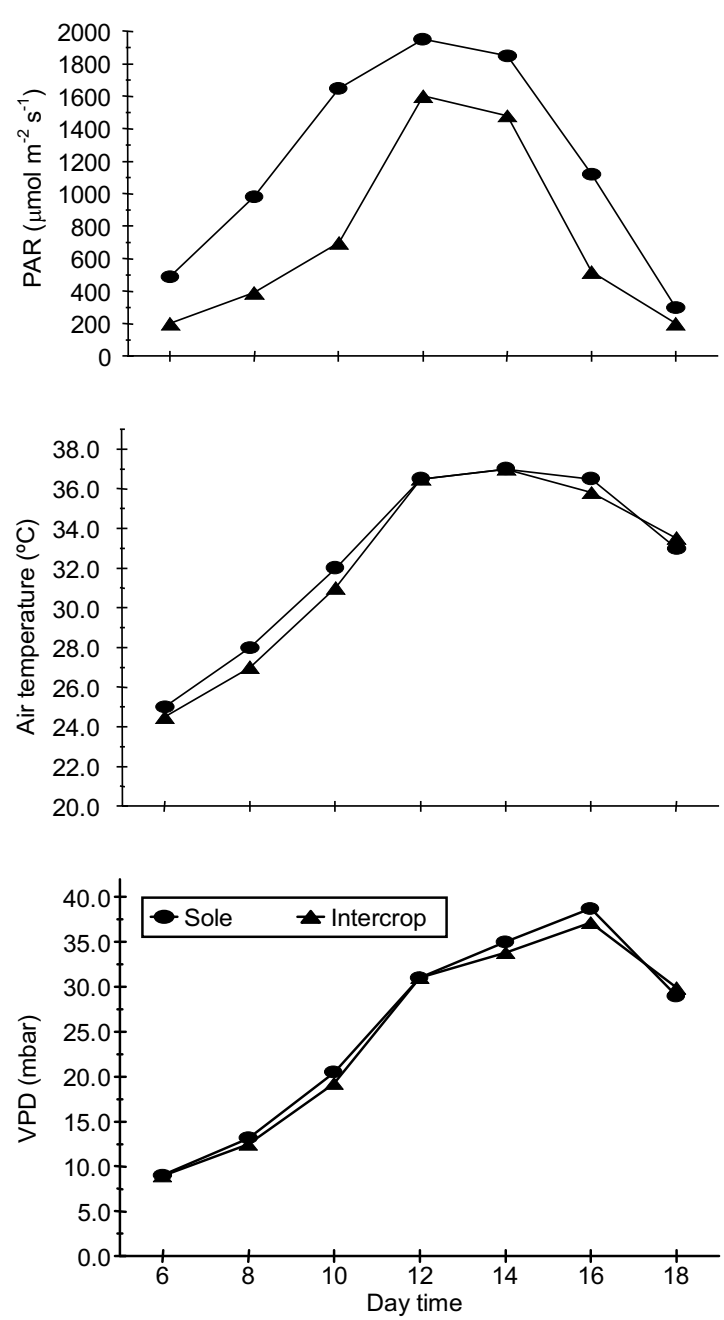

FIG. 1. Diurnal fluctuation on photosynthetic active radiation (PAR), air temperature (T), and vapor pressure deficit (VPD) observed above maize and intercropped cowpea.

Pesq. agropec. bras., Brasília, v.35, n.5, p.915-921, maio 2000 
affected by intercropping, since significant $(\mathrm{P}<0.05)$ lower values were recorded for maize as sole crop (Fig. 3). The lowest values and the lower difference between systems occurred at $12 \mathrm{~h}$, when $-1.32 \mathrm{MPa}$ and -1.2 MPa were detected respectively for sole and intercropped maize. However, during the afternoon, when the evapotranspiratory condition increased, the differences between systems became significant $(\mathrm{P}<0.05)$, when values around $-1.23 \mathrm{MPa}$ and $-0.95 \mathrm{MPa}$ were detected. Recovery occurred in the late afternoon, but differences between systems were still observed.

Maize $\mathrm{g}_{\mathrm{s}}$, E and A (Fig. 3) were also positively affected by intercropping. Values recorded were significantly higher $(\mathrm{P}<0.05)$ for maize intercropped than for sole crop, mainly between $12 \mathrm{~h}$ and $16 \mathrm{~h}$. The highest differences were computed at $14 \mathrm{~h}$ when $\mathrm{g}_{\mathrm{s}}, \mathrm{E}$, and $\mathrm{A}$ of intercropped maize were respectively $0.215 \mathrm{~mol} \mathrm{~m}^{-2} \mathrm{~s}^{-1}, 7.05 \mathrm{mmol} \mathrm{m}^{-2} \mathrm{~s}^{-1}$ and $22.0 \mu \mathrm{mol} \mathrm{m}^{-2} \mathrm{~s}^{-1}$. In the sole system these variables reached $0.107 \mathrm{~mol} \mathrm{~m}^{-2} \mathrm{~s}^{-1}, 5.14 \mathrm{mmol} \mathrm{m}^{-2} \mathrm{~s}^{-1}$, and $17.4 \mu \mathrm{mol} \mathrm{m} \mathrm{s}^{-2}$.

Unlike maize, soil $\psi \mathrm{m}$ obtained within the rows of sole cowpea was higher than under intercropping (Fig. 2). The values reached -0.03 MPa and - $0.05 \mathrm{MPa}$, under sole crop and intercropped conditions. In this case, the substitution of one row of cowpea for maize may have favored the interspecific competition for soil water in space and time. However, cowpea leaf $\psi \mathrm{w}$ was significantly higher $(\mathrm{P}<0.05)$ in intercrop-

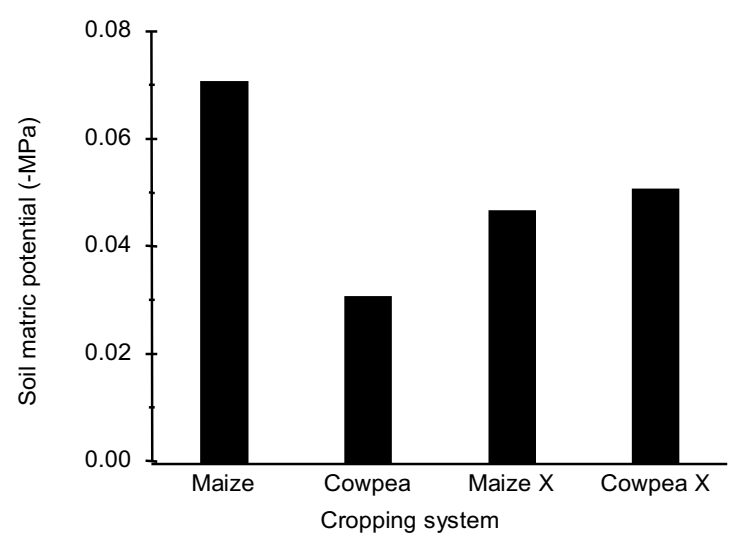

FIG. 2. Soil matric potential obtained within the rows of maize and cowpea as sole crops and intercropped (X).
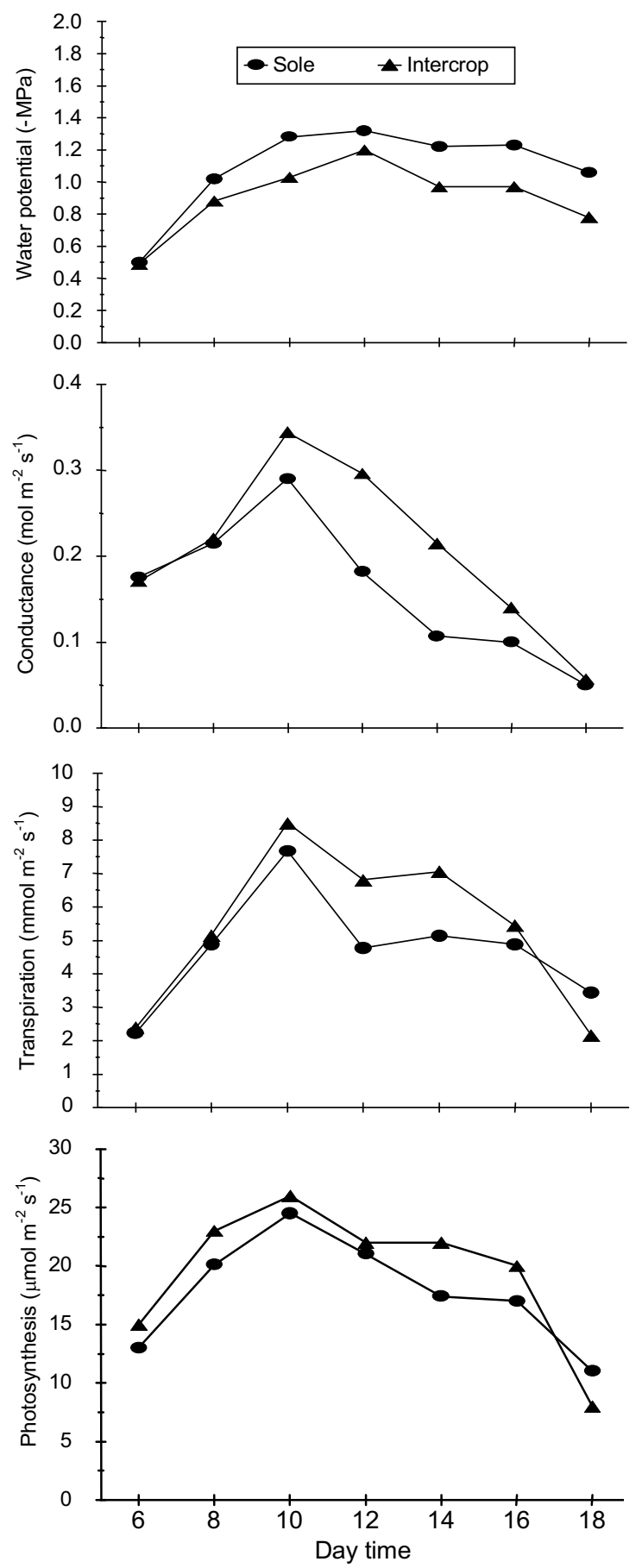

FIG. 3. Diurnal fluctuation on leaf water potential, stomatal conductance, transpiration and photosynthesis of maize as sole crop and intercropped with cowpea. 
ping than in sole crop (Fig. 4). The highest differences were recorded during the morning, mainly between $8 \mathrm{~h}$ and $10 \mathrm{~h}$, when the values reached around $-0.47 \mathrm{MPa}$ and $-0.69 \mathrm{MPa}$, respectively, for intercropped and sole cowpea. This is probably a consequence of full canopy exposition of the sole component to radiation causing rapid water loss from leaves. When intercropped, the radiation intercepted by maize leaves reduced considerably the energy input at the cowpea canopy level necessary for driving the evapotranspiration process. In fact, taller components can decrease the solar radiation load over the lower component (Natarajan \& Willey, 1981). Besides, they may act as windbreaks thus improving the water relations of the lower component (Radke \& Hagstron, 1976). Therefore, intercropped cowpea maintained higher leaf $\psi w$ than the sole crop. Shackel \& Hall (1984) reported that midday xylem water potential for cowpea plants intercropped with sorghum was higher than cowpea sole crop as a result of shading by sorghum plants. Similar results were also reported for soybean intercropped with sorghum (Wahua \& Miller, 1978).

Despite intercropped cowpea having reached higher $\psi w$, the observed $g_{s}$, E and A (Fig. 4) were lower than in the sole system, as a result of radiation interception by maize leaves. The highest differences between systems occurred during the morning, especially at $10 \mathrm{~h}$, when $\mathrm{g}_{\mathrm{s}}$, E and A of sole cowpea reached the highest values, respectively, $1.129 \mathrm{~mol} \mathrm{~m}^{-2} \mathrm{~s}^{-1}, 13.25 \mathrm{mmol} \mathrm{m}^{-2} \mathrm{~s}^{-1}$, and $23.0 \mu \mathrm{mol} \mathrm{m} \mathrm{m}^{-2} \mathrm{~s}^{-1}$. For intercropped cowpea, the values were $0.8 \mathrm{~mol} \mathrm{~m}^{-2} \mathrm{~s}^{-1}$, $9.74 \mathrm{mmol} \mathrm{m}^{-2} \mathrm{~s}^{-1}$ and $11.0 \mu \mathrm{mol} \mathrm{m} \mathrm{m}^{-2} \mathrm{~s}^{-1}$. However, under this situation the maximum values observed for cowpea were detected at noon, reaching $0.83 \mathrm{~mol} \mathrm{~m}^{-2} \mathrm{~s}^{-1}, 10.9 \mathrm{mmolm}^{-2} \mathrm{~s}^{-1}$ and $18.0 \mu \mathrm{molm}^{-2} \mathrm{~s}^{-1}$, respectively. At this point, with the sun overhead, the differences between systems were not significant with these variables almost reaching the values observed for sole cowpea. Thus, the differences in light environment between systems may have influenced these results.

Plant growth was not significantly influenced by intercropping (Fig. 5). The LAI of sole maize and cowpea were 3.36 and 2.8 , respectively. Under intercropping conditions, these values dropped to 1.6 and 1.39 , meaning $47.6 \%$ and $49.6 \%$ of the sole val-
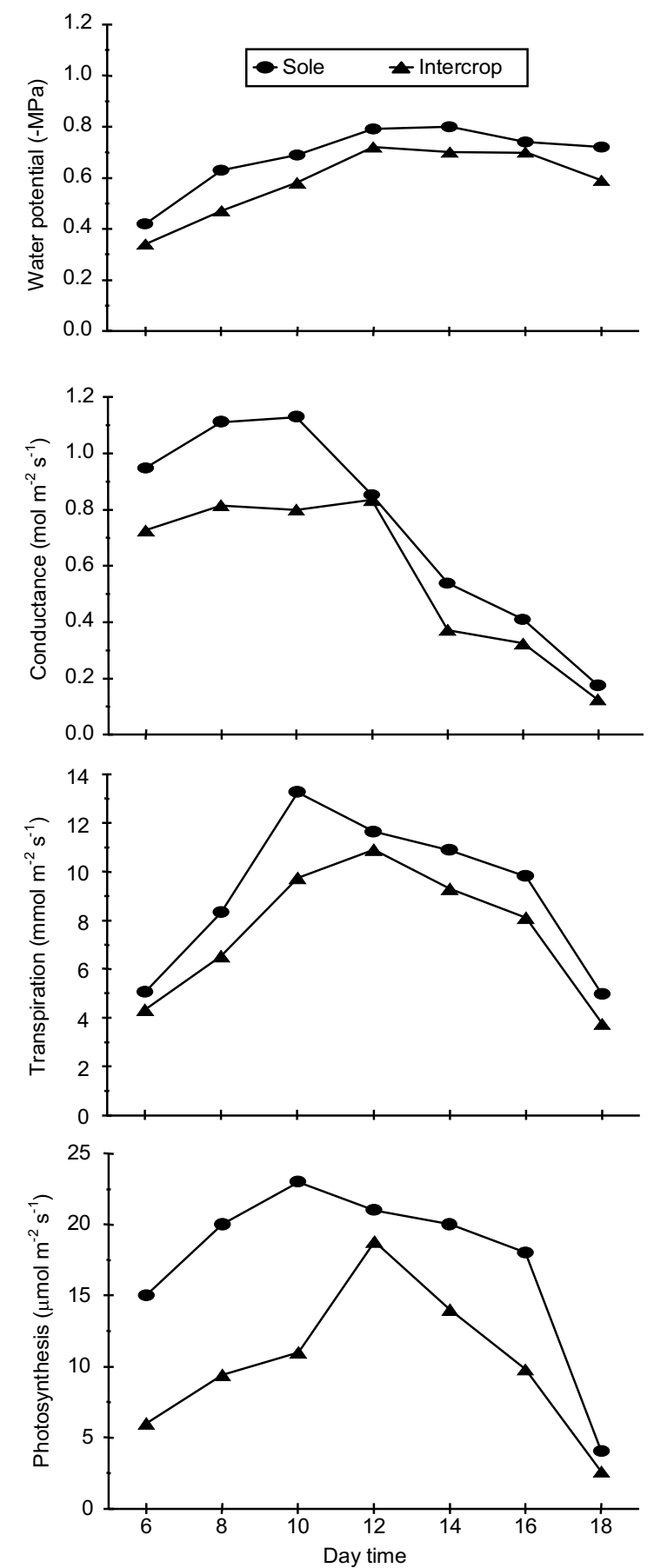

FIG. 4. Diurnal fluctuation on leaf water potential, stomatal conductance, transpiration and photosynthesis of cowpea as sole crop and intercropped with maize. 
ues. Since population of the intercropped components was $50 \%$ of the sole treatments, the observed decrease in LAI was only apparent.

Maize productivity was $2,208 \mathrm{~kg} \mathrm{ha}^{-1}$ and $1,500 \mathrm{~kg} \mathrm{ha}^{-1}$, respectively, as sole crop and intercropped (Table 1). Applying the same argument stated for LAI, one can realize an increase of $18 \%$ in productivity in relation to sole crop. For cowpea, the productivity was $1,550 \mathrm{~kg} \mathrm{ha}^{-1}$ as sole crop and $700 \mathrm{~kg} \mathrm{ha}^{-1}$ when intercropped, suggesting a decrease of $5 \%$ in relative yield. However, the LER value obtained was 1.13 , indicating intercropping advantage over the sole system (Table 1).

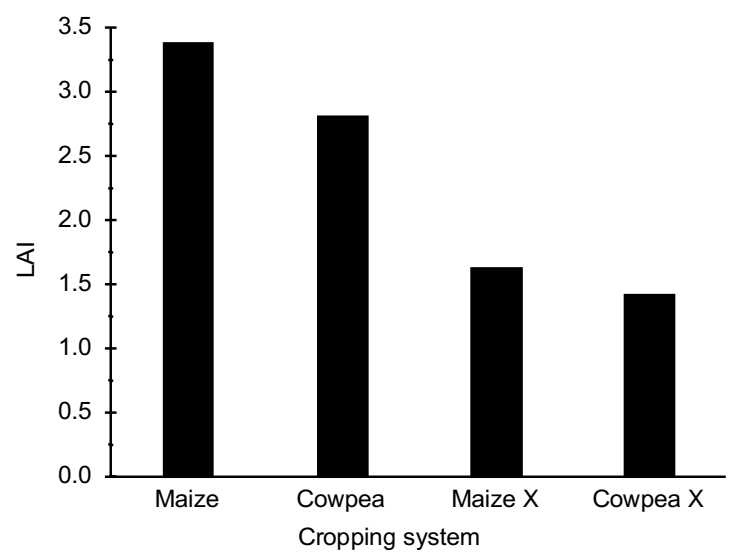

FIG. 5. Leaf area index (LAI) recorded for maize and cowpea as sole crops and intercropped (X).

TABLE 1. Grain productivity of maize and cowpea in both systems and values of partial and total land equivalent ratio (LER).

\begin{tabular}{lcc}
\hline Cropping system & Yield $\left(\mathrm{kg} \mathrm{ha}^{-1}\right)$ & Partial LER \\
\hline Maize sole & 2,208 & - \\
Maize intercropped & 1,500 & 0.68 \\
Cowpea sole & 1,550 & - \\
Cowpea intercropped & 700 & 0.45 \\
\hline Total LER & & 1.13 \\
\hline
\end{tabular}

\section{CONCLUSIONS}

1. Intercropping improves water relations and gas exchange of maize, compared to the sole situation.

2. Intercropped maize is more competitive than cowpea in terms of use of resources, mainly soil water.

3. The modification of light environment by maize canopy affects positively the water relations of intercropped cowpea; however, gas exchange processes are negatively influenced.

4. The higher partial LER obtained for maize suggests that this species was the main component influencing the productivity of the intercropping system studied.

5. The total LER obtained indicates that the intercropping outyields monocrops by $13 \%$.

\section{REFERENCES}

ALLEN, J.R.; OBURA, R.K. Yield of corn, cowpea and soybean under different intercropping systems. Agronomy Journal, Madison, v.75, p.1005-1009, 1983.

CHANG, J.F.; SHIBLES, R.M. An analysis of competition between intercropped cowpea and maize. Field Crops Research, Amsterdam, v.12, p.145-152, 1985.

CHOUDHURY, E.N.; MILLAR, A.A. Características físico-hídricas de três latossolos irrigados do projeto Bebedouro. Petrolina : Embrapa-CPATSA, 1981. 14p. (Embrapa-CPATSA. Boletim de Pesquisa, 4).

FORTIN, M.C.; PIERCE, F.J. Leaf azimuth in strip-intercropped corn. Agronomy Journal, Madison, v.88, n.1, p.6-9, 1996.

FRANCIS, C.A.; FLOR, C.A.; TEMPLE, S.P. Adapting varieties for intercropping systems in the tropics. In: PAPANDICK, R.I.; SANCHEZ, P.A.; TRIPLETT, G.B. (Eds.). Multiple cropping. Madison : American Society of Agronomy, 1976. p.235253.

GHAFFARZADEH, M.; PRÉCHAC, F.G.; CURSE, R.M. Tillage effect on soil water content and corn yield in strip intercropping system. Agronomy Journal, Madison, v.89, n.6, p.893-899, 1997. 
MEAD, R.; WILLEY, R.W. The concept of land equivalent ratio and advantage in yield from intercropping. Experimental Agriculture, Cambridge, Great-Britain, v.16, p.217-228, 1980 .

MORGADO, L.B.; RAO, M.R. População de plantas e níveis de água no consórcio milho $\mathrm{x}$ caupi. Pesquisa Agropecuária Brasileira, Brasília, v.20, n.1, p.4555, jan. 1985 .

NATARAJAN, M.; WILLEY, R.W. Growth studies in sorghum-pigeonpea intercropping with particular emphasis on canopy development and light interception. In: INTERNATIONAL WORKSHOP ON INTERCROPPING, 1979, Patancheru. Proceedings. Patancheru : ICRISAT, 1981. p.180-187.

OFORI, F.; STERN, W.R. Cereal-legume intercropping systems. Advances in Agronomy, San Diego, v.41, p.41-89, 1987.

OKIGHO, B.N.; GREENLAND, D.J. Intercropping systems in tropical Africa. In: PAPANDICK, R.I.; SANCHEZ, P.A.; TRIPLETT, G.B. (Eds.). Multiple cropping. Madison : American Society of Agronomy, 1976. p.63-101.

OLASANTAN, F.O. The effect of soil temperature and moisture content on crop growth and yield of intercropping maize and melon. Experimental Agriculture, Cambridge, Great-Britain, v.24, p.67-74, 1988.

RADKE, J.K.; HAGSTRON, R.T. Strip intercropping for wind protection. In: PAPANDICK, R.I.; SANCHEZ, P.A.; TRIPLETT, G.B. (Eds.). Multiple cropping. Madison : American Society of Agronomy, 1976. p.201-222.

RAO, M.R.; MORGADO, L.B. A review of maize-beans and maize-cowpea intercrop systems in the semiarid Northeast Brazil. Pesquisa Agropecuária Brasileira, Brasília, v.19, n.2, p.179-192, fev. 1984.
ROO, H.C. de. Leaf water potentials of sorghum and corn estimated with the pressure bomb. Agronomy Journal, Madison, v.51, p.989-992, 1969.

SHACKEL, K.A.; HALL, A.E. Effect of intercropping on water relations of sorghum and cowpea. Field Crops Research, Amsterdam, v.8, p.381-387, 1984.

TÁVORA, F.J.A.F.; LOPES, L.H. de O. Deficiência hídrica no consórcio milho $\mathrm{x}$ cowpea. Pesquisa Agropecuária Brasileira, Brasília, v.25, n.7, p.1011-1022, jul. 1990.

TURNER, N.C. Techniques and experimental approaches for the measurement of plant water status. Plant and Soil, Dordrecht, v.58, n.7, p.339-366, 1981.

VANDERMEER, J.H. Intercropping. In: CARROLL, C.R.; VANDERMEER, J.H.; ROSSET, P.M. (Eds.) Agroecology. New York : McGraw-Hill, 1990. p.481-516.

VANDERMEER, J.H. The interference production principle: an ecological theory. BioScience, Washington, v.31, p.361-364, 1981

VANDERMEER, J.H. The interpretation and design of intercrop systems involving environmental modification by one of the components: a theoretical framework. Biological Agriculture and Horticulture, Bicester, v.2, p.135-156, 1984.

WAHUA, T.A.T.; MILLER, D.A. Leaf water potential and light transmission in intercropped sorghum and soybean. Experimental Agriculture, Cambridge, Great-Britain, v.14, p.373-378, 1978.

WILLEY, R.W. Intercropping: its importance and research needs. Part 1. Competition and yield advantages. Field Crop Abstracts, Amsterdam, v.32, p.1-10, 1979.

WILLEY, R.W. Resource use in intercropping systems. Agricultural Water Management, Amsterdam, v.17, p.215-231, 1990. 